\title{
Guidance and Counseling of Capital Social-Based Entrepreneurial Training of Package C Program
}

\author{
Dayat Hidayat \\ Nonformal Education Department \\ Faculty of Teachers Training and Education \\ University of Singaperbangsa Karawang, Karawang, Indonesia \\ Dayathidayat194@gmail.com
}

\begin{abstract}
The study analyzes entrepreneurial guidance and counseling and capital social-based entrepreneurial training of a package $C$ program. This study used literature analysis method by doing a comparative study of various sources and conducted in-depth analysis to find a conclusion that could be justified scientifically. The results of the study concluded that entrepreneurial guidance and counseling were conducted to the learners of Package $\boldsymbol{C}$ through partnership assistance to cultivate entrepreneurial attitudes and skills. Also, the planning of entrepreneurship training was conducted by identifying learning needs, human and natural resource excellence as social capital, and business opportunities developed by learners of Package $C$. In the implementation of entrepreneurship training, the learners learned and practiced entrepreneurship skills. Assessment of training was conducted to measure the success of increasing knowledge, attitudes and entrepreneurship of learners.
\end{abstract}

\section{Keywords-Project-Based Learning; Interest and Creativity}

\section{INTRODUCTION}

Equality Education Package $\mathrm{C}$ is an equivalent non-formal education that highlights the mastery of science, technology, and the development of professional attitude and personality. In the implementation of the Package, $\mathrm{C}$ program is integrated with skills education oriented to the development of entrepreneurship. Package $\mathrm{C}$ program is implemented to improve the knowledge, attitude, and skill of striving for the learners. The existence of the entrepreneurial Package C-based program is now required by the community due to the rapid economic progress that requires skills that formal education cannot fulfill. The entrepreneurial Package C-based program is expected to address the problems facing the people learning Package $\mathrm{C}$ in its economic life. Through entrepreneurship training as a process of economic empowerment that emphasizes the critical ability of learners of Package $\mathrm{C}$ to analyze every situation and economic, social, and political potential faced, and develop further skills to improve their standard of living (Kindervatter, S. 1979: 12-13).

In the development of entrepreneurship, Package $\mathrm{C}$ program has not obtained maximum results. The Package $\mathrm{C}$ learners do not have the knowledge, skills, and entrepreneurial attitude is good enough. One feasible way to improve the knowledge, skills, and attitudes of entrepreneurial skills of Package $\mathrm{C}$ learners is through entrepreneurial guidance and counseling.
Nowadays, in developing the entrepreneurial attitude of the learners of Package $\mathrm{C}$, the role of instructors in guiding and entrepreneurial counseling is very important. The guidance aims to increase individual realization of each individual (Bernard \& Fullmer in Salahudin, A. (2009:13). This means that counseling is the process of helping individuals actualize themselves with the environment. A counseling is a method of guidance that aims to provide services to clients. Entrepreneurship guidance and counseling for learners of Package $\mathrm{C}$ is conducted to foster, develop and assist entrepreneurship through integrating entrepreneurial materials into curricula/programs in units and types of nonformal education. The guidance and counseling of entrepreneurship conducted by instructors on the entrepreneurship training program aim to grow and to build entrepreneurial mindset, improve attitudes and business behavior, and business management for the learners of Package $\mathrm{C}$.

The condition of Package $\mathrm{C}$ program above is in line with the research of Lisa, K.G, et al. (2014). This research presents an examination of familial influence on strategic entrepreneurial behaviors within a transitional economic context. The study investigates the relationships between risktaking propensity, entrepreneurial intensity, and opportunity recognition of the entrepreneur and the innovative orientation of the firm and sustainability.

Based on the above background, this research was conducted to analyze the guidance and entrepreneurship counseling program through training of entrepreneurship based on social capital for learners of Package $\mathrm{C}$ program. This research was conducted by using the qualitative descriptive method of theory analysis related to guidance and counseling, as well as entrepreneurship training based on capital social sources from various sources of literature. The results describe entrepreneurial guidance and counseling conducted to the learners of Package $\mathrm{C}$ through partnership assistance to cultivate entrepreneurial attitudes and skills. The planning of entrepreneurship training is carried out by identifying the learning needs, human and natural resource excellence, as well as the business opportunities developed by the learners of Package C.

The implementation of entrepreneurship training learns and practices entrepreneurship skills. Assessment of the training was conducted to measure the success of knowledge, skills, and entrepreneurial attitude of the learners of Package $C$. The 
impact of entrepreneurship guidance and counseling programs based on social capital is expected to improve economic empowerment of the families of Package $\mathrm{C}$ learners.

Basically, empowerment is placed on individual and social forces. Empowerment is defined as a psychological understanding of the influence of individual control over social circumstances, political forces and rights by law (Rappaport, 1987). McArdle (1989) defines empowerment as a decisionmaking process by people who consequently carry out the decision (Hikmat, H. 2010: 3).

\section{METHOD}

This research was conducted by using the descriptive qualitative method of literature study. This study aims to examine the concept through theoretical analysis. The researcher identified, studied and then cataloged data to derive conclusions about guidance and counseling concepts, as well as training on social capital-based entrepreneurship that was observed directly or indirectly. The theoretical concept is the main data. Researcher interprets data and facts to obtain an explanation of the concept of guidance and counseling, as well as social entrepreneurship training social capital-based economic empowerment for Package $\mathrm{C}$ learners that collected precisely and clearly to take conclusions. Technical analysis of data used in this study is an interactive model implemented through the stages of data collection, data reduction, display data, and conclusion/verifying (Miles \& Huberman, 1994).

\section{STUDY AND DISCUSSION}

\section{A. Entrepreneurship Guidance and Counseling}

The main task of Package $\mathrm{C}$ instructors on social capitalbased entrepreneurial training is to provide assistance or guidance of learning and strive to individual learners or groups related to entrepreneurship teaching materials. Sertzer and Stone (1976: 3) suggest that guidance comes from the word guide which means to direct, pilot, manager or steer, meaning: showing, directing, determining, organizing, or steering (Victoria Neufeldt, Ed., 1988: 599 in Salahudin, A., 2009: 13).

Winkel, W.S. (2005: 27) defines guidance as: (1) an attempt to equip individuals with knowledge, experience, and information about themselves; (2) a way to provide assistance to the individual to understand and use efficiently and effectively all opportunities that he has for his personal development; (3) a kind of service to individuals so that they can make choices, set goals appropriately, and devise realistic plans then they can adapt to satisfy themselves in the environment in which they live; (4) the process of providing assistance or help to the individual in terms of selfunderstanding, linking the understanding of himself with the environment, choosing, determining, and drafting the plan according to himself concept and environmental demands.

Furthermore, in relation to the definition of counseling, Prayitno, and Amfi, E. (2014: 105) suggest that the process of providing assistance is done through an interview counseling by an expert (counselor) to individuals who are experiencing a problem (clients) which leads to the problem that the client faced. Correspondingly, Winkel, W.S. (2005: 34) defines counseling as the essential set of activities of counseling in assisting counselees/clients face-to-face with the aim that clients can take on their own responsibility for specific issues or problems.

From the statements above, it has been explained the sense of guidance and counseling, which at first glance there are similarities and differences. However, the real guidance and counseling are two complementary work activities.

Drucker, P.F. (1994: 27) argues that entrepreneurship will appear to be the natures, characters, and attributes attached to someone who has a strong willingness to realize innovative ideas into the real world of business and can develop them. Zimmerer, T.W. \& Norman, M. S. (1996: 51), on the other hand, suggest "entrepreneurship is applying creativity and innovation to solve the problem and exploit that people faced everyday. Entrepreneurship is the ability to enrich the life of the people.

Kamil, M. (2007: 120) suggests that from some senses of entrepreneurship, can get the description of the purpose of entrepreneurship ranging from simple to more complete are : (1) realize innovative ideas from someone in the field of business, (2) create something new and different in business, (3) change the economic order by introducing products, services, creating, managing and exploring new raw materials in business, (4) a process for doing something new, (5) creating innovation and creativity to solve problems in the field of business, (6) develop ideas and find new ways of solving problems and exploit opportunities in the field of business, (7) finding new ways of thinking and doing so in such ways in the field of business

The goal of entrepreneurship according to Alma, B. (2007: 31 ) is to create welfare for others by finding new ways to use resources, reduce waste, and open up favorable employment opportunities. Therefore, for that purpose contained nodes associated with new concepts, management, creation, prosperity, and risk mitigation, and utilization of business capability.

Sudjana, D. (2004:130) suggests entrepreneurial requirements as a stage to be passed by entrepreneurs, namely: (1) identifying objectives to be achieved, (2) preparing for risks that will arise such as money, time and opportunity, 3) believe in the ability to plan, organize, coordinate, and execute business, (4) engage in hard work over time and prioritize mutual success, (5) work creatively with confidence to build and develop good relationships with customers, staff, banks, suppliers, government officials, and other influential parties in their business, (6) accepting challenges, self-employed with full responsibility for the success and failure of their business.

\section{B. Training on Social Capital-Based Entrepreneurship}

The term training is more often equated meaningful with a number of teaching or a series of subjects, both implemented within the organization and outside the organization. However, there are other ways that are used to learn more effectively. Training tends to focus on specific goals such as running machines, following new rules (Glaser, 1962). Training objectives introduce more new behaviors or change existing behaviors to create new levels of behavior. Training is 
designed to improve the performance of learners. (Nadler, 1982: 40-41).

The objective of entrepreneurship training for the learners of Package $\mathrm{C}$ in practice should be to achieve three dimensions of entrepreneurship, namely managerial skill, production technical skill, and personality development skill of entrepreneurship. The three main aspects of the essence are to instill the attitude and spirit of independence and the ability to cooperate and embed the entrepreneurial paradigm in the learners of Package $\mathrm{C}$.

The role of instructors in entrepreneurship training for learners of Package $\mathrm{C}$ emerged through the planning, implementation, and assessment phases. At the planning stage, the manager and instructors of Package $\mathrm{C}$ identifies the learning needs, advantages, disadvantages, and business opportunities according to the social capital condition of the learning community. In the implementation phase, instructors of Package $\mathrm{C}$ involves people learning to learn knowledge and practice entrepreneurship attitude and skill. In the assessment phase, instructors of Package $\mathrm{C}$ involves managers' participations, instructors and learners together measuring the improvement of knowledge, attitude and entrepreneurship felt and experienced by the learning community.

The role of instructors performs guidance and entrepreneurial counseling to the learners aimed at developing the attitude and entrepreneurial spirit in order to have innovative and creative abilities in running the business. The process of guidance and entrepreneurship counseling is a form of assistance to the community to learn sustainably and systematically, conducted instructors of Package $\mathrm{C}$ so that residents learn to understand himself, his environment and can exert himself and adjust to the environment to develop his potential optimally to develop his business for the welfare of himself and public welfare.

Social capital in entrepreneurship training for learners of Package $\mathrm{C}$ is an investment to acquire new resources in improving people's welfare. Social capital is believed to be one of the main components in mobilizing togetherness, mobility, developing ideas, mutual trust, and mutual benefit to achieve mutual progress in the community environment.

The research Renko et al. (2009) analyzed the effect of entrepreneurial orientation on product innovation and capital investment. According to him, entrepreneurship orientation is an important factor that positively influences product innovation and capital investment.

Social capital as a number of resources, actual or virtual, collected on an individual or group because it has a longlasting network of reciprocal relations of introduction and recognition that are slightly more institutionalized. In order for such social capital to survive its value, the individual must pursue it (Bourdieu and Wacquant, 1992: 119).

Based on the analysis of results, it can be seen that one of the problems that occur in various developing countries the main factor is due to low social capital that grows and develops in the community. The research Wu, et al. (2008) analyzed the intellectual impact of capital, including the entrepreneurial orientation, on corporate innovation and found that the moderating effects of entrepreneurial orientation outweigh other intellectual variables of capital. Coleman, J.S. (1988: 9) develops the concept of social capital as a way of integrating social and economic theory, claiming that social capital and human capital are generally complementary. Social capital offers an alternative to the concept of human capital, with emphasis on the collective because the concept of human capital only sees individuals who pursue their personal interests (Schuller, T., 2000).

The optimization of social capital in developing entrepreneurial Package $\mathrm{C}$ is expected to improve the results of training, entrepreneurship counseling, and counseling to the learning community which has an impact on economic independence and community welfare. The Package C-based entrepreneurship program is sustained by various management efforts to optimize social capital for improving the economic welfare of the people.

Entrepreneurship training based on social capital that is integrated through entrepreneurial guidance and counseling for learners of Package $\mathrm{C}$ becomes one of the solutions to the improvement of the people's economy.

In the context of community-based entrepreneurship, the research of Parwez, S. (2017) concludes that community-based entrepreneurship is considered to be an important instrument for the realization of potential among marginal and deprived communities isolated from the mainstream economy and is important in bringing social movement. Cultural values, shared resources, linkages, and mutual trust work for the community, nurtured through close personal relations for the functioning of economic activities. Entrepreneurial activities creating local public goods for a community have a comparative advantage over the absolute market-oriented activities.

The role of instructors to carry out guidance and counseling on the entrepreneurial Package $\mathrm{C}$ program plays an important role in supporting the economic development of community based on social capital in an integrated manner.

\section{CONCLUSION}

Based on the study which has been mentioned above, it can be concluded that:

A. The role of Package $\mathrm{C}$ instructors in providing entrepreneurial guidance and counseling to the learning community is a form of self-education and selfdevelopment of leaners learning about knowledge, attitudes and entrepreneurial skills. Entrepreneurial guidance and counseling is a systematic and sustained form of assistance to complement the ability of learners of Package $\mathrm{C}$ with knowledge, experience, and skills in entrepreneurship. 
$B$. Entrepreneurship training is a learning process that aims to foster and build entrepreneurial mindset, improve attitudes and business behavior, and business management for leaners learning Package C. Entrepreneurship training for learners of Package $\mathrm{C}$ is a learning process pursued by building soul and spirit, develops the mental attitude and entrepreneurial character, develops thinking power and ways of entrepreneurship, promotes and develops selfmotivating, understanding and mastering techniques in dealing with risks, competition and a process of cooperation, understanding and mastering the ability to sell ideas, and have the ability to manage the business they run.

\section{REFERENCES}

[1] Alma. B, 2007. Entrepreneurship. Bandung: Alfabeta.

[2] Bourdieu and Wacquant, 1992. An Invitation to Reflexive Sociology. Chicago: Univercity of Chicago Press.

[3] Coleman, J.S, 1988. Social Capital in The Creation of Human Capital. American Journal of Sociology. 94: 95-120.

[4] Drucker. P.F, 1994. Innovation and Entrepreneurship, Practice and Principle. New York: Harper Business.

[5] Glaser, R, 1962. Training Research and Education. (Ed). Pittsburgh: University of Pittsburgh Press.

[6] Hikmat, H, 2010. Community Empowerment Strategy. Bandung: Humaniora Press.

[7] Kamil, M, 2007. Education and Training (Concepts and Applications). Bandung: Alfabeta.

[8] Kindervatter, S. 1979. Non-formal Education as An Empoworing Process. Massachusetts: Center for International Education The University of Massachusetts.

[9] Lisa K.G. et al, 2014. Women-owned Family Businesses In Transitional Economies: Key Influences On Firm Innovativeness And Sustainability. Journal of Innovation and Entrepreneurship. 3(1): 2-17.
[10] McArdle, 1989. Community Development Tolls of Trade, Community Quartely Journal. 16.

[11] Milles, M.B. \& Huberman, A.M,. 1994. Qualitative Data Analysis, Jakarta: Universitas Indonesia Press.

[12] Nadler, L. 1982. Designing Training Program, The Critical Events Model. Sidney: Addison Wesley Publishing Company.

[13] Parwez, S, 2017. Community-Based Entre-preneurship: Evidence From A Retail Case Study. Journal of Innovation and Entrepreneurship, 6(14): 6-14.

[14] Prayitno and Amfi, E. 2005. Basics of Counseling Guidance. Jakarta: Rineka Cipta.

[15] Rappaport, 1987. "Term of Empowerment: Toward a Theory of Community Psychology", Amarican Journal of Community Phycology, 15(2).

[16] Renko, M., Carsrud, A., dan Brannback, M. 2009. The Effect of a Market Orientation, Enterpreneurial Orientation, and Technological Capability on Innovativeness: A study of Young Biotechnology Ventures in the United States and in Scandinavia. Journal of Small Business Management. 47(3): 331-369.

[17] Salahudin, A. 2009. Guidance and Counseling. Bandung: Pustaka Setia.

[18] Schuller, T., 2000. 'Human and Social Capital: the search for appropriate technomehtology'. Policy Studies, 21(1): 25-35.

[19] Sertzer, B. and Stone, S.C. 1976. Fundamental of Guedance. Boston: HMC.

[20] Sudjana, D. 2004. Nonformal Education, Insight, History of Development, Philosophy, Theory of Support, Principles. Bandung: Falah Production.

[21] Winkel, W.S. 2005. Guidance and Counseling in Educational Institutions. Revised Edition, London: Gramedia.

[22] Wu, W., Chang, M., and Chen, C. 2008. Promoting Innovation through the Accumulation of Intellectual Capital, Social Capital, and Enterpreneurship Orientation, R\&D Management. 38(3): 265-277.

[23] Zimmerer, T. W., \& Norman, M. S. 1996. Entrepreneurship And The New Venture Formation. New Jersey: Prentice-Hall International, Inc 